DP ST-84-343

TECHNICAL DIVISION

SAVANNAH RIVER LABORATORY
CC: W. R. Stevens, III

R. M. Wallace

R. B. Ferguson

G. W. Wilds

M. A. Ebra

M. D. Boersma

M. J. Plodinec

G. T. Wright

J. P. Bibler

R. E. Edwards

L. F. Landon

C. A. Langton

D. D. Walker

SRL Records (4) 773.A

PMC File

ACC.NO.

+789
141,31

MEMORANDUM

February 29,1984

TO: G. W. WILDS/E. L. ALBENESIUS

FROM: J. R. FOWLER/J. R. COOK

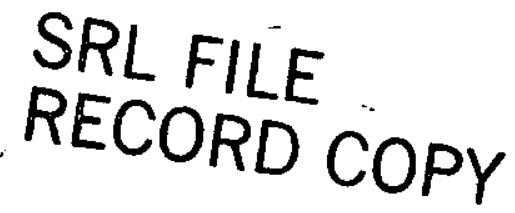

\title{
SUMMARY
}

An earlier tracer study in F-Area showed that a total of $1.3 \mathrm{Ci}$ of I-129 have been sent to the F-Area waste tanks based on the total curies of I-129 that have been processed through F-Area since plant startup. I However, only limited data have been available for H-Area.

To improve the data base for H-Area and ultimately for the entire waste inventory, additional soluble waste samples from H-Area waste tanks have been analyzed for I-129. Results from these analyses, earlier analyses of waste samples ${ }^{2}$ and the tracer data for F-Area show that the I-129 inventory in high-level waste is significantly less than previously assumed in the DWPF Technical Data summary 3,4

Decontaminated salt to be sent to saltstone will contain an average of $0.14 \mathrm{nCi}$ I-129 per gram of salt. This level is a factor of 5 lower than $0.70 \mathrm{nCi}$ per gram of salt that was calculated from the value shown in the DWPF flowsheet.4 Based on this source term, 
groundwater concentration of I-129 will be $0.07 \mathrm{pci} / 1 \mathrm{iter}$. This level is well below the EPA Drinking water limit of 1 pCi/liter.

Sludge contains less than 5 pci per gram, the detection limit of the analytical method used.10 Because of the low concentration of I-129 in the sludge, only a small fraction of the I-129 will be processed through the glass melter in the DWPF. Using the values shown above for I-129 and the projected annual waste throughput in the DWPF, $30.045 \mathrm{mCi}$ of $I-129$ will be released to the atmosphere each year. This level is less than 0.18 of the estimated 0.2 Ci per year released to the atmosphere from the Separations Areas. ${ }^{5}$ An iodine absorption bed in the DWPF is probably not economically justified for this low release rate.

\section{INTRODUCTION AND DISCUSSION}

\section{Background}

Long-lived isotopes in nuclear waste can have the greatest impact on man and the environment because of the integrated dose over a long time period. Many long-lived radioactive isotopes-are present in the waste at Savannah River Plant (Table I). Actinide elements make up a significant portion of these isotopes. But when the waste is incorporated into a glass waste form, the actinides are converted to chemically stable oxide species that are released at extremely low and controlled rates, even after the waste form has degraded.

Because of their different chemistry, radioactive isotopes of carbon, technetium, and iodine could be released at a significantly higher rate. To establish the potential hazard from these isotopes, their concentration in waste forms for final disposal must be known.

The concentrations of $\mathrm{C}-14$ and $\mathrm{TC}-99$ in SRP waste were previously estimated.4,6,7 Additional analytical data has now been obtained for I-129 in H-Area soluble waste to estimate its concentration in SRP waste. Because of the nature of processes at SRP, most of the I-129 in the waste is in the H-Area waste tanks.

\section{Chemistry of Iodine}

The chemistry of iodine shows that it will be a component of the soluble waste either as iodide or iodate salts.4,8 Thus most of the I-129 in the waste tanks will follow the soluble waste stream to saltstone. Only a small fraction of the I-129 in the waste will be processed through the melter in the DWPF.

The chemistry of iodine in F-Area separation processes is summarized in Table II. Most of the iodine that is processed through F-Area is volatilized as hydriodic acid (HI) during target dissolution in 
nitric acid. HI is oxidized to iodine in the dissolver off-gas and is subsequently removed from the off-gas by reacting with silver nitrate on berl saddles at 300 degrees in an iodine reactor. 1 The berl saddles containing silver iodide are periodically removed from the reactor and sent to the burial ground.1,9 Any iodide retained in aqueous process streams in F-Area is rejected either to the waste tanks with neutralized waste or to the seepage basins with evaporator overheads.

The chemistry of iodine in H-Area separation processes is summarized in Table III. Mercury(II), used as a catalyst to co-dissolve aluminum and uranium in the fuel tubes, forms insoluble mercury(II) iodide. Consequently, little iodine is lost to the dissolver offgas stream as HI. Subsequent head-end treatment with potassium permanganate may oxidize iodide to iodate, but mexcury(II) iodate is also insoluble. The iodine is thus diverted to the waste neutralization tank in the H-Area canyon. A portion of the iodine also follows evaporator overheads to the seepage basin. When H-Area waste containing iodine is neutralized with $\mathrm{NaOH}$, insoluble mercury(II) iodide or iodate is converted to mercury(II) oxide and the iodide or iodate is released as a soluble sodium salt.

Results

\section{I-129 in F-Area Waste}

Using $I-131$ as a tracer, the relative distribution of iodine among various waste streams in $F$-Area was established by separations Technology. 1 Using this distribution and the quantity of I-129 processed through F-Area as a basis, a total of $1.3 \mathrm{Ci}$ of I-129 have been diverted to the F-Area waste tanks from startup through 1980. In earlier analyses, 2 I-129 was not detected in samples of purex HAW and LAW sludge.

\section{I-129 in H-Area Waste}

HM HAW supernate samples from Tanks $11 \mathrm{H}, 12 \mathrm{H}$, and $15 \mathrm{H}$ were previously analyzed for $\mathrm{I}-129.2$ These samples showed $7.6 \mathrm{E}-8 \mathrm{Ci} / 1,2.8 \mathrm{E}-7$ $\mathrm{Ci} / 1$, and $2.9 \mathrm{E}-8 \mathrm{Ci} / 1$ of $\mathrm{I}-129$, respectively. sludge samples from Tanks $15 \mathrm{H}$ and $13 \mathrm{H}$ were also analyzed for $\mathrm{I}-129.2$ I-129 was not detected in these sludge samples.

To broaden the data base for H-Area soluble waste, an "as-received" HAW supernate sample from Tank 32H, a concentrated supernate sample from Tank 30 and salt samples from Tanks $9 \mathrm{H}$ and $10 \mathrm{H}$ were analyzed for I-129 using the Neutron Activation Method recently developed. 10 In the Tank $32 \mathrm{H}$ sample, $9.6 \mathrm{E}-8 \mathrm{Ci} / 1$ was found. The sample from Tank 30 contained $3.0 \mathrm{E}-7 \mathrm{Ci} / 1$. Analyses of salt samples from Tanks $9 \mathrm{H}$ and $10 \mathrm{H}$ showed that $\mathrm{I}-129$ concentration in the salt was less than 5 picocuries per gram of salt (the detection limit of the analyses). 11 
Based on total hydroxide analyses of the Tank 32 and Tank 30 supernate samples, "as-received" supernate is concentrated by a factor of 3.1 to produce concentrated supernate. This compares favorably to a concentration factor of 3.2 found for I-129. These results show that I-129 is neither crystallizing with the salt nor distilling from the waste during evaporation. Analyses of the salt from Tanks 9 and 10 also confirm that the $1-129$ is not crystallizing with the salt. 11

\section{Estimate of the I-129 in SRP Waste}

The total amount of I-129 in the waste was calculated using the results cited above and the inventory of salt, supernate, concentrated supernate, and sludge in the waste tanks.12-15 The total inventory of sludge and soluble waste and the calculated I-129 inventory were then used to calculate the average concentration of I-129 in soluble and insoluble waste components. Results from these calculations are summarized in Table IV.

\section{I-129 and Saltstone}

The latest mathematical modeling work done by Intera Environmental Consultants indicates that using the current saltstone formulation the concentration of I-129 in groundwater should be $0.33 \mathrm{pCi} / \mathrm{liter}$, using the old source term. Decreasing the source term by a factor of 5 decreases the groundwater concentration to 0.07 pCi/liter, which is somewhat over an order of magnitude below the EPA National Primary Drinking water Regulation limit of 1 pCi/liter. This provides an additional safety margin in saltstone for this environmentally significant radionuclide.

\section{Atmospheric Release of I-129 From The DWPF}

Present design of the melter off-gas system assumes all of the iodine fed to the melter will be volatilized as sodium iodide. In the off-gas system, 18 of the total iodide is converted to $I_{2}$. The molecular iodine that is formed will be vented to the atmosphere unless an iodine reactor is incorporated into the DWPF off-gas system. $3^{\text {an }}$

The combined sludge and supernate feed to the DWPF will contain the highest concentration of $\mathrm{I}-129$ because more soluble waste will reach the melter when the feed includes the stream from salt decontamination. Using the combined feed as a basis, 264 metric tons of sludge and 23 metric tons of soluble waste will be fed to the DWPF annually when the DWPF is operating at its maximum throughput. 3 Based on the average concentration of $I-129$ in the sludge $(5 \mathrm{pCi} / \mathrm{g})$ and the soluble waste $(0.14 \mathrm{nCi} / \mathrm{g})$, a total of $4.5 \mathrm{mCi}$ of I-129 will be fed to the melter annually. Using present design assumptions for the 
G. W. WILDS, et.al. $\quad \begin{array}{ll}\text { DPST-84-343 } \\ \quad-5- & \text { February } 29,1984\end{array}$

DWPF off-gas system, only $0.045 \mathrm{mCi}$ of the I-129 fed to the melter will follow the noncondensible gas stream that is vented to the atmosphere. Even if all $4.5 \mathrm{mCi}$ of the I-129 fed to the melter were vented, the annual release would be insignificant. Based on this low release rate, an iodine reactor in the DWPF off-gas system does not appear to be economically justified.

\section{I-129 Source Term for The DWPF Flowsheet}

A new source term and solubility factor for use in the DWPF flowsheet have been calculated for I-129. Results of these calculations are shown in Table V. The old source term and solubility are also shown for comparison.

\section{QUALITY ASSURANCE}

The best available data at the time of writing were used in the estimates shown in this report. The quality of new analytical data on H-Area samples is covered by ADD's QA program. Historical records were reviewed to assure that values reported here are consistent with prior estimates. Because of uncertainties associated with estimating the waste inventory and using average compositions, the values shown here should not be construed to be more accurate than indicating the approximate order of magnitude. This level of accuracy is adequate for design purposes.

JRF : pmc

Att

12 
G. W. WILDS, et.al: $\quad-6-\quad \begin{array}{ll}\text { DPST-84-343 } & \text { February 29, } 1984\end{array}$

\section{REFERENCES}

1. CORNMAN, W. R., "Estimation of I-129 Distribution in SRP Separations Processes," DP ST-74-533, November 21, 1974, (SECRET).

2. ALBENESIUS, E. L., personal communication (also see J. R. FOWLER, DP STN-3302, p 69).

3. LANDON, L. F., and THOMPSON, T. T., compilers, "Technical Data Summary for the Defense waste Processing Facility: Stage 1 (DPSTD-80-38-2) and stage 2 (DPSTD-80-39-2)".

4. FOWLER, J. R., "Update of Chemical and Radiochemical Composition of Decontaminated Soluble waste from the Precipitation Process," DPST-82-759, August 6, 1982 .

5. ASHLEY C., and ZEIGLER, C. C., "Releases of Radioactivity at the Savannah River Plant," DPSPU-75-25-1, February 1980.

6. FOWLER, J. R. and COLEMAN, C. J., "Carbon-14 in Sludge," DP ST-83-2001, December 28, 1983.

7. FOWLER, J. R., HAMM, B. A., and COOK, J. R., "Technetium-99 in SRP Waste and Saltstone," DPST-84-334, to be issued.

8. JONES, JR., W. N., General Chemistry, Blakiston Company Inc., New York (1954).

9. HAWKINS, R. H., Personal communication.

10. RYAN, J. P., "The Analysis of Decontaminated Defense waste Salt Supernate for I-129," DPST-83-325, February 23, 1983.

11. J. R. FOWLER, DP STN-3302.

12. FOWLER, J. R., "Calculated Composition of F Area Soluble High Level Waste", DPST-82-390, March 10, 1982.

13. FOWLER, J. R., "Calculated Composition of $\mathrm{H}$ Area and SRP Soluble High Level Wasten, DP ST-82-502, April 28, 1982.

14. EIBLING, R. E. and FOWLER, J. R., "Updated Waste Composition at The Savannah River Plant," DPST-83-313, March 1983.

15. EIBLING, R. E. and FOWLER, J. R., "Waste composition at the Savannah River Plant," DPST-82-897, October 4, 1982. 
G. W. WILDS, et.al.

\section{TABLE I}

\section{LONG-LIVED RADIOACTIVE ISOTOPES IN SRP WASTES}

\section{Isotopes}

$x-129$

TC-99

C-14

Pu-239

$\mathrm{U}-235$

Pa-231

$\mathrm{U}-238$

$\mathrm{U}-234$

Th-230
Half-Life, Yr

$16,000,000$

210,000

5,700

24,000

$700,000,000$

33,000

$4,470,000,000$

244,000

77,000
Daughter

Xe-129 (stable)

Ru-99 (stable)

N-14 (stable)

$\mathrm{U}-235$

$\mathrm{Th}-231=\mathrm{Pa}-231$

Multiple to $\mathrm{Pb}-207$ (stable)

$\mathrm{U}-234$

Th-230

Multiple to $\mathrm{Pb}-206$ (stable) 
G. W. WILDS, et.al . DP ST-84-34 3

February 29, 1984

TABLE II

\section{PROCESS CHEMISTRY FOR IODINE IN F-AREA}

A. Dissolver

$\mathrm{MI}+\mathrm{HNO}_{3}=\mathrm{HI}+\mathrm{MNO}_{3}$

B. Dissolver of $f-G a s$

$4 \mathrm{HI}+\mathrm{O}_{2}=2 \mathrm{I}_{2}+2 \mathrm{H}_{2} \mathrm{O}$

C. Iodine Reactor

$\mathrm{I}_{2}+\mathrm{NO}+\mathrm{H}_{2} \mathrm{O}+2 \mathrm{AgNO}_{3}=2 \mathrm{AgI}+2 \mathrm{HNO}_{3}+\mathrm{NO}_{2}$

D. Waste Neutralization

$\mathrm{MI}+\mathrm{NaOH}=\mathrm{NaI}+\mathrm{MOH}$ 


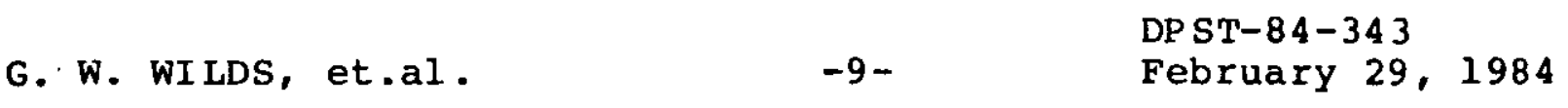

\section{TABLE III}

\section{PROCESS CHEMISTRY FOR IODINE IN H-AREA}

A. Dissolver

$\mathrm{MI}+\mathrm{Hg}\left(\mathrm{NO}_{3}\right)_{2}=2 \mathrm{MNO}_{3}+\mathrm{HgI}_{2}$

B. Head-End

$\mathrm{HgI}_{2}+4 \mathrm{KMnO}_{4}=\mathrm{Hg}\left(\mathrm{IO}_{3}\right)_{2}+4 \mathrm{MnO}_{2}+2 \mathrm{H}_{2} \mathrm{O}$

c. Waste Neutralization

$\mathrm{Hg}\left(\mathrm{IO}_{3}\right)_{2}+2 \mathrm{NaOH}=2 \mathrm{NaIO}_{3}+\mathrm{HgO}+\mathrm{H}_{2} \mathrm{O}$

$\mathrm{HgI}_{2}+2 \mathrm{NaOH}=2 \mathrm{NaI}+\mathrm{HgO}+\mathrm{H}_{2} \mathrm{O}$ 

G. W. WILDS, et.al .

\section{TABLE IV}

\section{INVENTORY OF I-129 IN THE WASTE TANKS}

Waste

Component

HM HAW

Conc. Supernate

Salt

HM LAW

F-Area Waste

Total salt

Solids

sludge

- Analysis show 9.12 Ci I-129 in tank farm (99.88 soluble).
Total I-129

$1.0 \mathrm{Ci}$

$300 \mathrm{nCi} / 1 \quad 5.6 \mathrm{Ci}$

$<5 \mathrm{pCi} / \mathrm{g} \quad 0.1 \mathrm{Ci}$

$\begin{array}{ll}(=\mathrm{HM} \text { HAW }) & 1.1 \mathrm{Ci}\end{array}$

$1.3 \mathrm{Ci}$

$8.13 \mathrm{El} 0 \mathrm{~g}$

$0.14 \mathrm{nCi} / \mathrm{g}$

$9.1 \mathrm{Ci}$

$3.08 \mathrm{Eg} \mathrm{g}$

$<5 \mathrm{pCi} / \mathrm{g}$

$0.02 \mathrm{Ci}$ 
G.

$\begin{array}{ll}\text { G. W. WILDS, et.al. } & \text { DPST-84-343 } \\ \text { February } 29,1984\end{array}$

\section{TABLE V}

I-129 SOURCE TERM FOR THE DWPF FLOWSHEET

$\mathrm{Ci} / \mathrm{Gal}$

\& Soluble

Isotope

$\underline{\text { old }}$

New

이모

New

I-129

9. $5 \mathrm{E}-7$

$1.9 \mathrm{E}-7$

99.9

99.83 